\title{
Phytochemical Composition and Evaluation of the Antioxidant Activity of the Ethanolic Extract of Calendula suffruticosa subsp. suffruticosa Vahl
}

\author{
Sofiane Ismahene ${ }^{1 *}$, Seridi Ratiba ${ }^{1}$, Cortes Martinez Diego Miguel ${ }^{2}$, Cabedo Nuria ${ }^{2}$
}

\section{Sofiane Ismahene ${ }^{1 *}$, Seridi Ratiba ${ }^{1}$, Cortes Martinez Diego Miguel'2, Cabedo Nuria $^{2}$}

\section{'Laboratory of Plant Biology and Environnement "Médicinal Plants» Axis, Faculty of Sciences University Badji Mokhtar-Annaba. BP 12, 23000 Annaba, ALGERIA. \\ ${ }^{2}$ Laboratory of Pharmacognosy Av. Vicente Andrés Estelle s / 46100 Burjassot, Valencia, SPAIN. \\ Correspondence}

Sofiane Ismahene

Cité 11/12/1960 Bt"G", Bloc 4 N 508 Annaba, ALGERIA.

Phone no: 2130698103764

E-mail: sofiane-ismahene@hotmail.fr

History

- Submission Date: 03-08-2017;

- Review completed: 31-08-2017;

- Accepted Date: 02-11-2017

\section{DOI : 10.5530/pj.2018.1.13}

Article Available online

http://www.phcogj.com/v10/i1

Copyright

(C) 2018 Phcog.Net. This is an openaccess article distributed under the terms of the Creative Commons Attribution 4.0 International license.

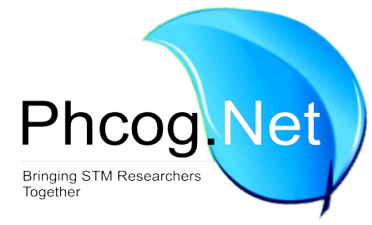

\begin{abstract}
Aim: Calendula suffruticosa ssp. suffruticosa Vahl, Medicinal and Aromatic plant, spontaneous and widespread in the Mediterranean region and in the Northeast of Algeria, is widely used by the local population for its medicinal properties. Methods: The chemical composition of the ethanolic extract of Calendula suffruticosa was established for the first time using GC / MS. The antioxidant activity of the ethanolic extract was evaluated in vitro by the DPPH (2,2-diphenyl-1-picrylhydrazyl) test, the FRAP assay and $\beta$-carotene bleaching assay. Results: sixty-four compounds are identified by GC/MS analysis, six are predominant: $\alpha$-linoleic acid (24.20\%), linoleic acid (23.58\%), Stigmasterol (8.53\%), 2-Metyl-Z-4-tetradecene (6.62\%) And $\alpha$-Bisabolol (1.70\%). The free radical scavenging by DPPH method indicated that the ethanolic extract of $C$. suffruticosa showed a very high antioxydant activity with an $I C_{50}=0.017 \pm 1.00$ $\mathrm{mg} / \mathrm{ml}$. This extract also showed an ability to reduce very high iron with a maximum optical density of 1.157 at a concentration of $0.5 \mathrm{mg} / \mathrm{ml}$ and an antioxidant activity compared to the $\beta$-carotene / linoleic acid test of order of $75 \pm 1.02 \%$. Conclusion: These results show for the first time the richness of phytochemicals and the strong antioxidant activity of the species Calendula suffruticosa endemic to north-east of Algeria.

Key words: Calendula suffruticosa, GC / MS, Phytochemical composition, Antioxidant activity, DPPH, FRAP.
\end{abstract}

\section{INTRODUCTION}

Calendula is a genus of about 12 to 20 species originating from Macaronesia and the Mediterranean. ${ }^{1}$ They are popular medicinal herbs well known throughout the world because of their vast areas of biological activities such as antimicrobial, anti-oxidant, anti-mutagenic, hepatoprotective, healing and anti-inflammatory.

The species Calendula suffruticosa Vahl, is a perennial and viscous herbaceous plant, belonging to the family Asteraceae and reaching about $40 \mathrm{~cm}$ in height; the stem is upright. ${ }^{2}$ It is usually wooded at some distance above the base, simple or little branched. ${ }^{3}$ The leaves are of a pale green color and lanceolate, slightly wavy and toothed. The flowers are united in capitules exceeding $2 \mathrm{~cm}$ in diameter and of yellow or orange color, the peripheral flowers are tied and united in two rows, while those in the center are tubular and toothed; the fruit is an achene often curved and equipped with peaks. $^{2}$

The genus name of the "Calendula" dates back to the Middle Ages, it comes from the Latin "Calendar": The calends being in the Roman calendar on the first day of the month, probably with a sense analogous to calendar, metrological indicator because of its long period of flowering because the heads open and close with the appearance of the sun. ${ }^{4}$ While suffruticosa, derived from the Latin "frutex" means bush which brings this woody species closer to the sub-shrubs. ${ }^{2}$

Numerous phytochemical investigations carried out on Calendula species such as C. officinalis and C. arvensis show that they constitute an enormous reservoir of potentially active natural molecules, the majority of which are essential oils, ${ }^{1,2,3,4}$ Flavonoids, ${ }^{6,7,8,9}$ the saponosides, ${ }^{10}$ Carotenoids, ${ }^{11,12,13}$ Organic acids, saccharides, sterols and lipids. ${ }^{9}$

While the species Calendula suffruticosa subsp suffruticosa Vahl. has not been the subject of any phytochemical or pharmacological studies to our knowledge.

Due to the economic value of species of the genus Calendula as medicinal plants and their uses in cosmetics, pharmaceutical preparations and food industry, and the limited number of phytochemical and pharmacological studies of these species in Algeria.

In this study, we are interested in studying for the first time the chemical composition of the ethanolic extract of the endemic Calendula suffruticosa subsp suffruticoa Vahl species in northeastern Algeria, and

Cite this article: Sofiane I, Seridi R, Cortes DM, Cabedo N. Phytochemical Composition and Evaluation of the Antioxidant Activity of the Ethanolic Extract of Calendula suffruticosa subsp. suffruticosa Vahl. Pharmacog J. 2018;10(1):64-70. 
the evaluation of the antioxidant activity of this species by three different methods. It should be noted that to date, no studies on the chemical composition and biological activity of Calendula suffruticosa subsp suffruticoa Vahl. has been made.

\section{SUBJECTS AND METHODS}

\section{Chemical reagents}

Ethanol,2,2-diphenyl-1-picrylhydrazyl (DPPH), 2,6-di-tert-butyl4-hydroxycarboxylic acid (BHT), butylated hydroxy anisole (BHA), Linoleic acid, aluminum chloride $\left(\mathrm{AlCl}_{3} \cdot 6 \mathrm{H}_{2} \mathrm{O}\right)$ and quercetin are from Sigma-Aldrich (USA). Ascorbic acid and gallic acid are from BIOCHEM Chemo pharma (Monteral, Quebec).

Iron (III) chloride $\left(\mathrm{FeCl}_{3} \cdot 6 \mathrm{H}_{2} \mathrm{O}\right)$ and Potassium permanganate $\left(\mathrm{KMnO}_{4}\right)$ are from PROLABO Chemical.

\section{Plant material}

The samples of Calendula suffruticosa were collected in full bloom and fruiting in March 2015 in the Edough region "Cap de Fer" (20 km northeast of the town of Annaba, Algeria).

The botanical identification of the species was made according to Quezel and Santa, (1962-1963) ${ }^{14}$ and validated by Doctor HAMEL. T, TeacherResearcher in Plant Physiology, Department of Biology, Annaba University, Algeria.

\section{Preparation of the ethanolic extract of Calendula suffruticosa Vahl}

The extraction was carried out according to the method of Rigane et al. $(2013)^{8}$ to which we added some modifications.

Different organs of C. suffruticosa, previously cleaned and ground, are macerated in $90 \%$ ethanol with agitation for $24 \mathrm{~h}$ at room temperature. The ethanol extract is recovered after filtration of the mixture using a filter paper, the ethanol is removed from the filtrate by evaporation under reduced pressure in a rotary evaporator.

The extract obtained is characterized by a dark green color (blackish green), which is the crude extract. It is then stored in an amber flask at $4^{\circ} \mathrm{C}$. until the analysis time.

\section{GC/MS analysis}

The constituents of the ethanol extract were identified by GC / MS at the Mass Spectrometry laboratory of the Institute of Chemical Technology (ITQ) of Valencia (Spain).

The analysis was performed by a gas chromatograph of the type Chimadzu coupled to mass spectrometer. The capillary column was of type QP 2010 S of $25 \mathrm{~m}$ length and the diameter of $0.25 \mathrm{~mm}$. The flow rate of the carrier gas (helium) was $1 \mathrm{ml} / \mathrm{min} .3 \mu \mathrm{l}$ of the extract was injected using the split less mode. The column temperature was maintained at $90^{\circ} \mathrm{C}$ for $10 \mathrm{~min}$ and then increased to $20^{\circ} \mathrm{C}$ per min up to $220^{\circ} \mathrm{C}$ and finally $4^{\circ} \mathrm{C}$ per min up to $300^{\circ} \mathrm{C}$ for $20 \mathrm{~min}$. The ionization mode was by electron impact and the scanning range was between 40 and $620(\mathrm{~m} / \mathrm{z})$. The Mass spectra were obtained at 0-2-min intervals.

Identification of the compounds of the ethanol extract was carried out using the data base of the National Institute of Standards and Technology (NIST) and the Wiley spectra data base.

\section{Antioxidant activity}

The antioxidant activity in vitro of the ethanolic extract of C. suffruticosa was carried out according to three methods: scavenging of the free radical $\mathrm{DPPH}$, the beta-carotene bleaching test and the reduction of iron.

\section{Free radical scavenging DPPH}

The free radical scavenging activity was measured using the stable free radical DPPH which is one of the main tests used to explore the use of herbal extracts as antioxidants, the experimental protocol followed is according to Benhammou et al. (2007). ${ }^{15}$

Briefly, DPPH is solubilized in methanol to have a solution of $0.3 \mathrm{mM}$. $1 \mathrm{ml}$ of methanol and $1 \mathrm{ml}$ of the extract (at different concentrations $1 \mathrm{mg} / \mathrm{ml}$ in methanol) are introduced into tubes and $2 \mathrm{ml}$ of the methanol solution are added to the DPPH.

After stirring by a vortex, the tubes are placed in the dark at room temperature for $30 \mathrm{~min}$. The reading is performed by measuring the absorbance at $517 \mathrm{~nm}$.

The negative control is composed of $1 \mathrm{ml}$ of the DPPH methanol solution and $2.5 \mathrm{ml}$ of methanol. BHT, BHA and ascorbic acid were used as synthetic antioxidants of reference.

The capacity of the antioxidant to scavenge the free radical is estimated as a percentage of discoloration of the DPPH in solution in methanol.

The percentage of antioxidant activity was determined according to the following equation:

$\%$ Antioxidant activity $=($ Abs control - Abs sample $/$ Abs control $) \times 100$

The results are the average of two separate measurements \pm standard deviation

- Calculation of $\mathrm{IC}_{50}$

$\mathrm{IC}_{50}$ or $50 \%$ inhibitory concentration is the concentration of the test sample needed to reduce $50 \%$ of the DPPH free radical.

\section{Ferric reducing antioxidant power: FRAP assay}

The reduction activity is determined according to the method of OYAIZU (1986), ${ }^{16}$ based on the chemical reduction reaction of the iron (III) present in the complex K 3 Fe (CN) 6 in Iron (II). The absorbance is determined at $700 \mathrm{~nm}$.

The ethanolic extract diluted $(1 \mathrm{ml})$ at different concentrations was mixed with $2.5 \mathrm{ml}$ of the phosphate buffer solution $(0.2 \mathrm{M}, \mathrm{pH} 6.6)$ and $2.5 \mathrm{ml}$ of potassium ferricyanide ((K3Fe $(\mathrm{CN}) 6)$ at $1 \%)$. All incubated at $50^{\circ} \mathrm{C}$ for $20 \mathrm{~min}$. Then, $2.5 \mathrm{ml}$ of trichloroacetic acid (TCA) at $10 \%$ was added to the mixture to stop the reaction, Then the tubes are centrifuged for $10 \mathrm{~min}$ at $3000 \mathrm{rpm}$. Distilled water $(2.5 \mathrm{ml})$ and ferric chloride $(\mathrm{FeCl} 3)$ ( $500 \mu \mathrm{l}$ to $0.1 \%$ ) were added to $2.5 \mathrm{ml}$ of the supernatant. The absorbance was measured at $700 \mathrm{~nm}$ against a blank using a spectrophotometer.

Ascorbic acid was used as positive control at the same selected concentrations and in the same operating conditions as the samples.

\section{B-carotene bleaching method}

The experimental protocol followed is that of Ozsoy et al. (2008). ${ }^{17}$ To prepare the $\beta$-carotene emulsion, $2 \mathrm{mg}$ of that are dissolved in $10 \mathrm{ml}$ of chloroform, then $1 \mathrm{ml}$ of This Solution Is mixed with $20 \mathrm{mg}$ of purified linoleic acid and $200 \mathrm{mg}$ of Tween 40 . Then, the chloroform is evaporated under reduced pressure by a rotary evaporator at $40^{\circ} \mathrm{C}$. and the residue obtained is taken up in $50 \mathrm{ml}$ of oxygenated ultra-pure water.

Tubes containing $5 \mathrm{ml}$ of this emulsion are prepared, for which $200 \mu \mathrm{l}$ of extract and antioxidant (BHA) at different concentrations are added.

The mixture is well stirred and the absorbance is measured at $470 \mathrm{~nm}$ immediately at t 0 against a blank that contains the emulsion without the $\beta$-carotene. The covered tubes are incubated at $50^{\circ} \mathrm{C}$ and the absorbance is reading after $120 \mathrm{~min}$.

A negative control is realized in parallel, comprising $5 \mathrm{ml}$ of the emulsion of $\beta$-carotene and 200.mu. 1 of ethanol.

The results obtained are expressed in terms of percentage inhibition of the decoloration of $\beta$-carotene using the following formula: \% Inhibition $=\left[1-\left(A_{0}-A_{t} / A_{0}^{0}-A_{t}^{0}\right)\right] \times 100$

$\mathrm{A}_{0}$ : Absorbance of the sample at $\mathrm{t} 0$.

$A_{t}$ : Absorbance of the sample after 120 min of incubation. 
$\mathrm{A}_{0}{ }_{0}^{0}$ : Absorbance of the negative control at $\mathrm{t} 0$.

$\mathrm{A}_{\mathrm{t}}^{0}$ : Absorbance of the negative control after $120 \mathrm{~min}$ of incubation.

\section{RESULTS}

GC/MS analysis

The phytochemicals compounds of the ethanolic extract of the species Calendula suffruticosa, harvested in the Edough region of Annaba Province (Algeria) were identified by GC / MS for the first time Figure 1.

From the data collected from the chromatographs and spectra of mass spectrometry and after treatment of the results, we could identify 64 chemical compounds in the ethanolic extract of the aerial part of the species Calendula suffruticosa.

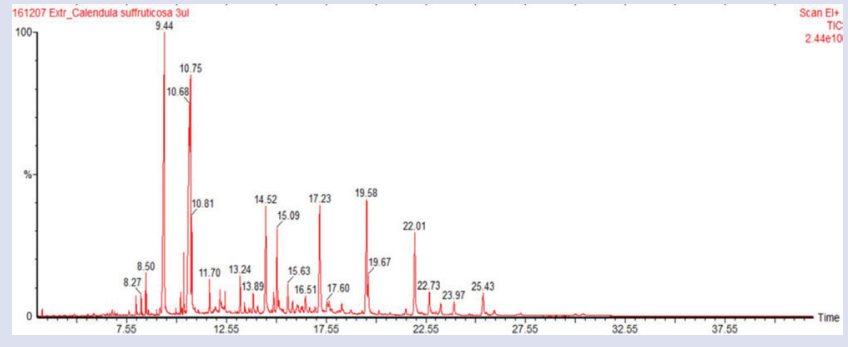

Figure 1: Chromatographic profile of the ethanolic extract of the aerial part of Calendula suffruticosa.

Table 1: Chemical compounds of the ethanolic extract of the aerial part of C. suffruticosa by GC-MS.

\begin{tabular}{|c|c|c|c|c|c|}
\hline No & $\begin{array}{l}\text { Retention } \\
\text { time }\end{array}$ & Name of Compound & $\begin{array}{l}\text { The molecular } \\
\text { formula }\end{array}$ & $\begin{array}{c}\text { The molecular } \\
\text { weight }\end{array}$ & $\begin{array}{c}\text { Percentage } \\
\text { (\%) }\end{array}$ \\
\hline 1 & 6.810 & Undecanoic acid & $\mathrm{C}_{11} \mathrm{H}_{22} \mathrm{O}_{2}$ & 186 & - \\
\hline 3 & 7.645 & a-Bisabolol & $\mathrm{C}_{15} \mathrm{H}_{26} \mathrm{O}$ & 222 & $1.70 \%$ \\
\hline 4 & 7.665 & 3-Buten-2-one,4-(4-hydroxy-2,2,6-trimethyl-7-axabicycol $(4,1,0)$ hept-l-yl- & $\mathrm{C}_{13} \mathrm{H}_{20} \mathrm{O}_{3}$ & 224 & - \\
\hline 5 & 8.015 & Myristic acid & $\mathrm{C}_{14} \mathrm{H}_{28} \mathrm{O}_{2}$ & 228 & - \\
\hline 7 & 8.185 & 7-Hexadecene, (Z)- & $\mathrm{C}_{16} \mathrm{H}_{32}$ & 224 & - \\
\hline 8 & 8.270 & Acetic acid,2-(2,2,6-trimethyl-7-axa-bicyclo $(4,1,10)$ hept-1-yl propenylester & $\mathrm{C}_{14} \mathrm{H}_{22} \mathrm{O}_{3}$ & 238 & $0.2 \%$ \\
\hline 9 & 8.335 & Bicycle $(3,2,1)$ octan-3-one, 6-(2-hydroxyethyl, endo- & $\mathrm{C}_{10} \mathrm{H}_{16} \mathrm{O}_{2}$ & 168 & $0.17 \%$ \\
\hline 10 & 8.496 & 3,7,11,15-Tetramethyl-2-hexadecen-1-ol & $\mathrm{C}_{20} \mathrm{H}_{40} \mathrm{O}$ & 296 & $0.22 \%$ \\
\hline 14 & 8.776 & 3-Octadecyne & $\mathrm{C}_{18} \mathrm{H}_{34}$ & 250 & - \\
\hline 15 & 9.051 & Palmitic acid, methyl ester & $\mathrm{C}_{17} \mathrm{H}_{34} \mathrm{O}_{2}$ & 270 & - \\
\hline 16 & 9.221 & Cis, cic, cis-7, 10,13-Hexadecatrienal & $\mathrm{C}_{16} \mathrm{H}_{26} \mathrm{O}$ & 234 & - \\
\hline 17 & 9.436 & Palmitic acid & $\mathrm{C}_{16} \mathrm{H}_{32} \mathrm{O}_{2}$ & 256 & $1.15 \%$ \\
\hline 18 & 10.011 & Margaric acid & $\mathrm{C}_{17} \mathrm{H}_{34} \mathrm{O}_{2}$ & 270 & $0.16 \%$ \\
\hline 19 & 10.241 & Nonadecane & $\mathrm{C}_{19} \mathrm{H}_{40}$ & 268 & - \\
\hline 20 & 10.271 & Linolelaidic acid, methyl ester & $\mathrm{C}_{19} \mathrm{H}_{34} \mathrm{O}_{2}$ & 294 & - \\
\hline 21 & 10.316 & Linolenic Acid, methyl ester & $\mathrm{C}_{19} \mathrm{H}_{32} \mathrm{O}_{2}$ & 292 & - \\
\hline 22 & 10.406 & Phytol & $\mathrm{C}_{20} \mathrm{H}_{40} \mathrm{O}$ & 296 & $1.20 \%$ \\
\hline 29 & 12.437 & Ocatdecane,6-methyl- & $\mathrm{C}_{19} \mathrm{H}_{40}$ & 268 & $1.13 \%$ \\
\hline 30 & 12.477 & Adipic Acid, bis(2-ethylhexyl) ester & $\mathrm{C}_{22} \mathrm{H}_{42} \mathrm{O}_{4}$ & 370 & $1.46 \%$ \\
\hline 31 & 13.242 & Octacosane & $\mathrm{C}_{28} \mathrm{H}_{58}$ & 394 & $0.22 \%$ \\
\hline 32 & 13.512 & Docosanoic acid, methyl ester & $\mathrm{C}_{23} \mathrm{H}_{46} \mathrm{O}_{2}$ & 354 & - \\
\hline 33 & 13.673 & $6 \beta$ Bicyclo $[4,3,0]$ nonane, $5 \beta$-iodomethyl- $1 \beta$-isopropenyl- $4 \alpha$-dimethyl- & $\mathrm{C}_{15} \mathrm{H}_{25}$ & 332 & - \\
\hline
\end{tabular}

Continued... 
Table 1: Cont'd.

\begin{tabular}{|c|c|c|c|c|c|}
\hline No & $\begin{array}{l}\text { Retention } \\
\text { time }\end{array}$ & Name of Compound & $\begin{array}{l}\text { The molecular } \\
\text { formula }\end{array}$ & $\begin{array}{l}\text { The molecular } \\
\text { weight }\end{array}$ & $\begin{array}{l}\text { Percentage } \\
\quad(\%)\end{array}$ \\
\hline 34 & 13.763 & Diisoctyl phathalate & $\mathrm{C}_{24} \mathrm{H}_{38} \mathrm{O}_{4}$ & 390 & - \\
\hline 35 & 13.893 & Docosanoic acid & $\mathrm{C}_{22} \mathrm{H}_{44} \mathrm{O}_{2}$ & 340 & $1.30 \%$ \\
\hline 36 & 14.113 & Tetradecane2,6,10-trimethyl- & $\mathrm{C}_{17} \mathrm{H}_{36}$ & 240 & - \\
\hline 37 & 14.523 & B-D-Mannofuranoside,farnesyl- & $\mathrm{C}_{21} \mathrm{H}_{36} \mathrm{O}_{6}$ & 384 & \\
\hline 38 & 14.923 & A-Himachalene & $\mathrm{C}_{15} \mathrm{H}_{24}$ & 204 & \\
\hline 39 & 15.173 & Humulane-1,6-dien-3-ol & $\mathrm{C}_{15} \mathrm{H}_{26} \mathrm{O}$ & 222 & $0.11 \%$ \\
\hline 40 & 15.873 & Lignoceric acid & $\mathrm{C}_{24} \mathrm{H}_{48} \mathrm{O}_{2}$ & 368 & \\
\hline 41 & 16.149 & Globulol & $\mathrm{C}_{15} \mathrm{H}_{26} \mathrm{O}$ & 222 & $0.24 \%$ \\
\hline 42 & 16.364 & Thujopsene & $\mathrm{C}_{15} \mathrm{H}_{24}$ & 204 & $0.13 \%$ \\
\hline 43 & 16.514 & $\begin{array}{l}\text { 5-(7a-isopropenyl-4,5-dimethyl-octahydroinden-4-yl) -3-methyl-penta-2,4- } \\
\text { dien-1-ol }\end{array}$ & $\mathrm{C}_{20} \mathrm{H}_{32} \mathrm{O}$ & 288 & $1.61 \%$ \\
\hline 44 & 16.999 & Ledol & $\mathrm{C}_{15} \mathrm{H}_{26} \mathrm{O}$ & 222 & $0.17 \%$ \\
\hline 45 & 17.224 & Nonacosane & $\mathrm{C}_{29} \mathrm{H}_{60}$ & 408 & $4.89 \%$ \\
\hline 46 & 17.704 & 4,8,13-Cyclotetradecatriene-1,3-diol,1,5,9-trimethyl-12-(1-methylethyl) - & $\mathrm{C}_{20} \mathrm{H}_{34} \mathrm{O}_{2}$ & 306 & $1.59 \%$ \\
\hline 47 & 18.334 & Heptacosane & $\mathrm{C}_{27} \mathrm{H}_{56}$ & 380 & - \\
\hline 48 & 19.670 & 2-Metyl-Z-4-tetradecene & $\mathrm{C}_{15} \mathrm{H}_{30}$ & 210 & $6.62 \%$ \\
\hline 49 & 20.210 & Vitamine E ( $\alpha$-tocopherol) & $\mathrm{C}_{29} \mathrm{H}_{50} \mathrm{O}_{2}$ & 430 & $0.25 \%$ \\
\hline 50 & 21.426 & $\begin{array}{l}\text { 1,2-Pentanediol,5-(6-bromodecahydro-2-hydroxy-2,5,5a,8a-tetramethyl-1- } \\
\text { naphtanyl }\end{array}$ & $\mathrm{C}_{20} \mathrm{H}_{35} \mathrm{BrO}_{3}$ & 402 & - \\
\hline 51 & 21.551 & Campesterol & $\mathrm{C}_{28} \mathrm{H}_{48} \mathrm{O}$ & 400 & $0.10 \%$ \\
\hline 52 & 22.006 & Stigmasterol & $\mathrm{C}_{29} \mathrm{H}_{48} \mathrm{O}$ & 412 & $8.53 \%$ \\
\hline 53 & 22.341 & 2-Hydroxy-1,1,10-trimethyl-6,9-epidioxydecalin & $\mathrm{C}_{13} \mathrm{H}_{22} \mathrm{O}_{3}$ & 226 & - \\
\hline 54 & 22.731 & $\beta$-sitosterol & $\mathrm{C}_{29} \mathrm{H}_{50} \mathrm{O}$ & 414 & $3.50 \%$ \\
\hline 55 & 22.941 & Ergosta-7,22-dien-3 $\beta$-ol,acetae & $\mathrm{C}_{30} \mathrm{H}_{84} \mathrm{O}_{2}$ & & - \\
\hline 56 & 23.066 & Oxalic acid,allyl pentadecyl ester & $\mathrm{C}_{20} \mathrm{H}_{36} \mathrm{O}_{4}$ & 340 & - \\
\hline 57 & 23.296 & Urs-12-en-24-oic acid,3-oxo-, methyl ester & $\mathrm{C}_{31} \mathrm{H}_{48} \mathrm{O}_{3}$ & 468 & - \\
\hline 58 & 23.781 & Kauran-18-al, 17-(acetyloxyl) -, (4ß) - & $\mathrm{C}_{22} \mathrm{H}_{34} \mathrm{O}_{3}$ & 346 & - \\
\hline 59 & 23.967 & a-Amyrin & $\mathrm{C}_{30} \mathrm{H}_{50} \mathrm{O}$ & 426 & $2.49 \%$ \\
\hline 60 & 24.112 & Androstan-3-one, 17-hydroxy-2,4-dimethyl-, $(2 \alpha, 4 \alpha, 5 \alpha, 17 \beta)$ - & $\mathrm{C}_{21} \mathrm{H}_{34} \mathrm{O}_{2}$ & 318 & - \\
\hline 61 & 24.727 & Methanol, [6,8,9-trimethyl-4-(propenyl) -3-oxabicyclo[3,3,1] non-6-en-1-yl] & $\mathrm{C}_{15} \mathrm{H}_{24} \mathrm{O}_{2}$ & 236 & - \\
\hline 62 & 25.432 & Lupeol & $\mathrm{C}_{30} \mathrm{H}_{50} \mathrm{O}$ & 426 & $3.76 \%$ \\
\hline 63 & 25.997 & 3,7,11,15-Tetramethyl-2-hexadecen-1-ol & $\mathrm{C}_{20} \mathrm{H}_{40} \mathrm{O}$ & 296 & - \\
\hline 64 & 27.293 & Pregn-16-en-20-one,3-hydroxy-, $(3 \beta, 5 \beta)$ - & $\mathrm{C}_{21} \mathrm{H}_{32} \mathrm{O}_{2}$ & 316 & - \\
\hline
\end{tabular}

The compounds identified with their retention time (RT), molecular formula (MF), molecular weight (MW) and peak area as a percentage are presented in Table 1.

This extract consists mainly of a linoleic acid (24.20\%), linoleic acid (23.58\%) Stigma sterol (8.53\%), 2-metyl-4-Z-tetradecene $(6.62 \%)$ and a-Bisabolol (1.70\%).

\section{Antioxidant activity}

\section{Free radical DPPH scavenging}

The antioxidant activity of the ethanol extract of Calendula suffruticosa and the standard antioxidants (ascorbic acid, BHA and BHT) against the DPPH radical was evaluated using a spectrophotometer.

The Figure 2 presents the inhibition percentages obtained from the ethanolic extract of $C$. suffruticosa compared with that of the positive controls used (BHA, BHT and ascorbic acid) as a function of the different concentrations used for scavenging of the free radical DPPH.
The values obtained have enabled us to trace curves having an exponential shape with the presence of a stationary phase which means the almost total reduction of DPPH in its non-radical form. This is reflected by the strong antioxidant activity of the standards which recorded high inhibition percentages of $97.72 \pm 0.13 \%$ for ascorbic acid, $96.92 \pm 0.04 \%$ for BHT, and $96.74 \pm 0.05 \%$ for BHA. The ethanolic extract of the aerial part of C. suffruticosa has also showed a strong antioxidant activity with a percentage reduction of DPPH of $92.07 \pm 0.05 \%$ Figure 2 .

By comparing the $\mathrm{IC}_{50} \mathrm{~s}$ of the standards with those of the extract tested, we note that the three positive controls used possess a powerful antioxidant activity which is superior to that of the extract studied.

BHA is the most active with a $\mathrm{IC}_{50}=0.0058 \pm 1.45 \mathrm{mg} / \mathrm{ml}$, followed by ascorbic acid and BHT $(0.0071 \pm 0.27 \mathrm{mg} / \mathrm{ml}$ and $0.0078 \pm 6.52 \mathrm{mg} / \mathrm{M1})$, respectively. The ethanolic extract of $C$. suffruticosa also showed a very high antioxidant activity with an $\mathrm{IC}_{50}=0.017 \pm 1.00 \mathrm{mg} / \mathrm{ml}$. 
Antioxidant activity:

Free radical DPPH scavenging:

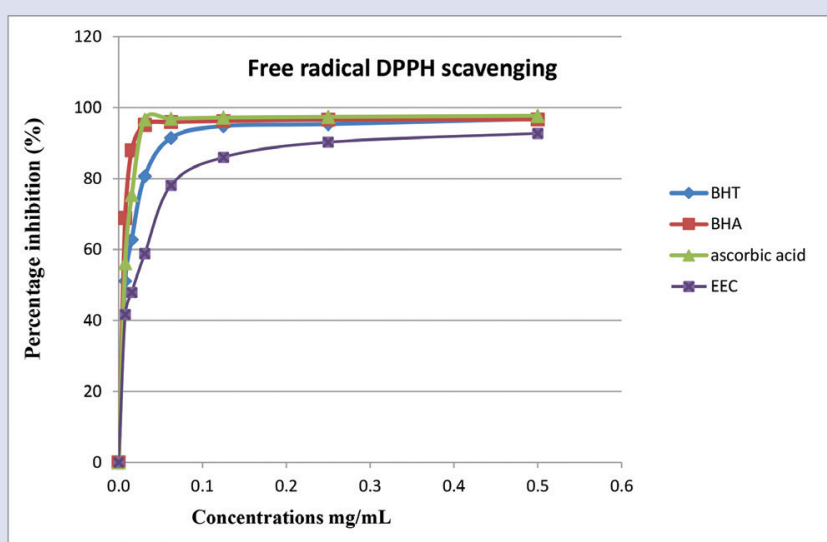

Figure 2: Anti-radical activity of the ethanol extract of Calendula suffruticosa. (Each value represents the mean of three trials \pm SD).

Antioxidant activity:

FRAP assay:

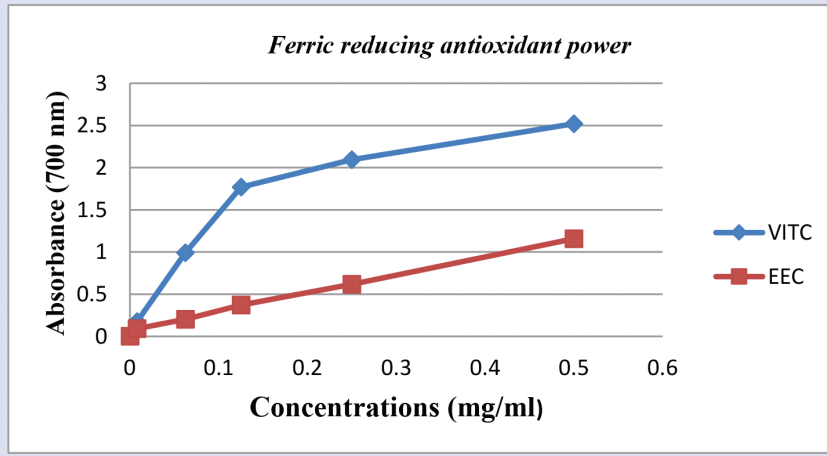

Figure 3: Reductive power of the ethanolic extracts of the studied plant and of the ascorbic acid tested by the FRAP assay.

\section{FRAP assay}

This method was described for the first time in 1996 by Benize and Strain. The FRAP method is a simple, inexpensive and robust spectrophotometric technique. It is based on the capacity of polyphenols to reduce ferric iron $\mathrm{Fe}^{3}$ into ferrous iron $\mathrm{Fe}^{2}{ }^{2}{ }^{18}$

The results of the reducing power of the ethanolic extract of C. suffruticosa and of ascorbic acid are represented in Figure 3.

The results obtained in FIG. (03) show that the capacity to reduce the iron of the ethanolic extract of the aerial part of C. suffruticosa is very high with a maximum optical density of 1.157 at a concentration of $0.5 \mathrm{mg} / \mathrm{ml}$. But it is clearly lower to that of ascorbic acid which represent a DO of $1.77 \mathrm{mg} / \mathrm{ml}$ at the concentration $0.1 \mathrm{mg} / \mathrm{ml}$ only.

\section{$B$-carotene bleaching assay}

Figure 4 presents the antioxidant power tested by the method of bleaching of $\beta$-carotene of the ethanol extract of C. suffruticosa.

According to our results, we clearly note that BHA exerts a strong antioxidant effect, with inhibition percentages up to $82.69 \pm 0.03 \%$.

\section{Antioxidant activity: \\ $\beta$-carotene bleaching assay:}

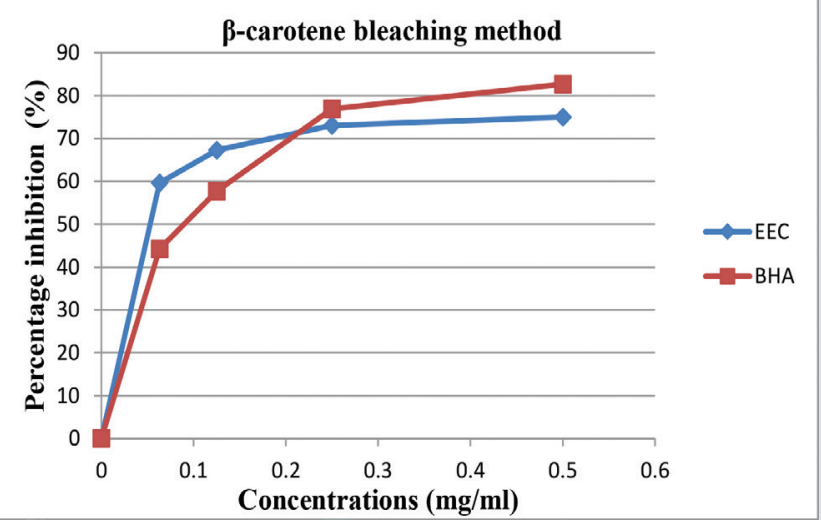

Figure 4: Antioxidant power of the ethanol extract of $C$. suffruticosa tested by the method of bleaching of $\beta$-carotene.

The extract tested also shows a strong inhibiting power of the coupled oxidation of linoleic acid and $\beta$-carotene with a percentage of $75 \pm 1.02 \%$ at the concentration $0.5 \mathrm{mg} / \mathrm{ml}$.

\section{DISCUSSION}

The ethanolic extract of the species Calendula suffruticosa, was identified by GC / MS for the first time. This extract consists mainly of a linoleic acid (24.20\%), linoleic acid (23.58\%) Stigma sterol (8.53\%), 2-metyl-4-Ztetradecene (6.62\%) and $\alpha$-Bisabolol (1.70\%).

We have not found in the literature information on the chemical composition of the ethanolic extract of the species Calendula suffruticosa. While the species Calendula officinalis has been the subject of numerous phytochemical investigations.

The results we have obtained of the phytochemical analysis agree with other scientific work reported on the species Calendula officinalis.

Various terpenoids were detected in the petroleum ether extract of $C$. officinalis flowers. They include sitosterol's, Stigma sterols ${ }^{19}$ Lupeol. ${ }^{20-21}$

In another study ${ }^{22}$, the petroleum ether extract of $C$. officinalis is rich in lipids such as: monol fatty acids, sterol esters, 3-monoesters, lauric acid, myristic acid, palmitic, stearic, oleic, linoleic and linolenic acid.

The existence of linoleic acid and stearic acid in the methanolic extract of the stem and the leaf of $C$. officinalis is also demonstrated with a percentage of 27.56 and $6.41 \%$ respectively. ${ }^{23}$

According to the results of GC / MS, the strong antioxidant activity of the ethanolic extract of C. suffruticosa is probably due to its richness of active ingredients which possess an antioxidant effect such as a tocopherol, campesterol, stegmasterol, $\beta$-sitosterol, Lupeol, $\alpha$-Bisabolol and linoleic a-acid.

The scavenging effect of the hydro-methanol extracts of $C$. officinalis and of the standard on the $\mathrm{DPPH}$ radical expressed in $\mathrm{IC}_{50}$ values were of the order: flowers (0.35 mg.ml-1), leaves (0.57 mg. Ml-1) and BHT (8.11 mg.ml -1). ${ }^{8}$ These data reveal that the extracts of the different parts probably have a stronger effect of trapping free radicals than the positive control (BHT).

The potentiality of the ethanolic extract of C. suffruticosa to reduce ferric iron $\mathrm{Fe}^{3+}$ into ferrous iron $\mathrm{Fe}^{2+}$ is related to the nature of the reducing substances existing in this extract. 
The antioxidant activity by the FRAP assay of methanolic extracts of the species C. officinalis collected in the Béja region of Tunisia was studied. The authors obtained values of $28.37 \pm 0.12$ and $17.68 \pm 0.02 \mathrm{mM}$ Trolox for the flowers and leaves respectively. ${ }^{8}$

In addition, the species Calendula arvensis of western Algeria, reported an antioxidant capacity of the essential oil of this species tested by FRAP test where it recorded the concentration of $90.7 \mu \mathrm{g} / \mathrm{mL}$ a reducing power of the $\mathrm{HE}$ of $C$. arvensis much higher with a value of $(\mathrm{DO}=1.698){ }^{24}$

In a similar study, the aqueous extract of $C$. officinalis at a concentration of $100 \mu \mathrm{g} / \mathrm{ml}$ showed anti-radical and antioxidant activities, by an inhibition rate of $74.6 \%$ of the lipid peroxidation of linoleic acid, this activity is higher than that of $\alpha$-tocopherol (63\%) which has been used as a standard. ${ }^{25}$

\section{CONCLUSION}

In this study, we studied for the first time the chemical composition and the antioxidant activity of the ethanolic extract of the species Calendula suffruticosa subsp suffruticoa Vahl endemic to north-east of Algeria. The analysis of the ethanol extract by GC-MS showed the presence of various bioactive compounds confirming the medicinal interest of this plant. The antioxidant activity of this extract is very important and comparable to some extent to synthetic antioxidants (BHA, BHT and ascorbic acid).

This extract could therefore constitute as alternative to certain synthetic additives. It is necessary to attract attention to the fact that these results are obtained in vitro.

Their interest resides in the fact that they allow to directly search the antioxidant activity of this extract or pure compounds in vivo to correlate the results observed in the two cases.

\section{CONFLICT OF INTEREST}

The authors are declared no conflict of interest.

\section{ABBREVIATION USED}

GC-MS: Gas chromatography mass spectrometry; FRAP: Ferric reducing antioxidant power; DPPH: 2,2-diphenyl-1-picrylhydrazyl; BHT: 2,6-ditert-butyl-4-hydroxycarboxylic acid; BHA : butylated hydroxy anisole; EEC: Ethanolic extract of Calendula suffruticosa.

\section{REFERENCES}

1. Paolini J, Barboni T, Desjobert JM, Djabou N, Muselli A, Costa J. Chemical composition, interspecies variation and seasonal variation in essential oils of Calendula arvensis L. Biochemical Systematics and Ecology. 2010;38(5):865-74.

2. Beniston N, Beniston W. Fleurs d'Algérie. Enterprise National du Livre. p.359;1984.

3. Tutin T, Heywood H. Flora Europaea: Plantaginaceae to Compositae (and Rubiaceae). Cambridge University Press. p.534;1976.

4. Couplan F, Les plantes et leurs noms: Histoires insolites. Editions Quae. p.223;2012.

5. Gazim ZC, Rezende CM, Fraga SR, Filho BP, Nakamura CV, Cortez DA. Analysis of the essential oils from Calendula Officinalis growing in Brazil using three different extraction procedures. Brazilian Journal of Pharmaceutical Sciences. 2008;44(3):391-5.

6. Wilen RW, Barl B, Slinkard AE. Feasibility of Cultivation Calendula as a Dual Purpose Industrial Oil seed and Medicinal Crop. Future for Medicinal and Aromatic Plants. 2004:199-206.

7. Masterova I, Grancaiová Z, Uhrínová S, Suchý V, Bik K, Nagy M. Flavonoids in flowers of Calendula Officinalis L. Chemis Papers. 1991;45(1):105-8.

8. Rigane G, Ben-younes S, Ghazghazi H, Ben-salem R. Investigation in to the biological activities and chemical composition of Calendula Officinalis L. growing in Tunisia. International Food Research Journal 2013;20(6):3001-7.

9. Albulescu M, Alexa N, Cojan C. Calendula Officinalis flowers, source of extracts with antioxidant activity. Annals of West University of Timisoara. Series Chemistry. 2004;13(2):169-76.

10. Kirmizibekmeza H, Bassarello C, Piacente S, Pizza C. Triterpene Saponins from Calendula arvensis. Verlag der Zeitschrift f" ur Naturforschung. 2006;61(9):1170-3.

11. Khalid KHA, Teixeira JA. Biology of Calendula Officinalis Linn: focus on pharmacologic, biological activities and agronomic practices. Medicinal and Aromatic Plant Science and Biotechnology. Medicinal and Aromatic Plant Science an Biotechnology. 2012;6(1):12-27.

12. Sausserde R, Kampuss K. Composition of carotenoids in Calendula (Calendula Officinalis I.) flowers. Foodbalt. 2014.

13. Pintea A, Bele C, Andrei S, Socaciu C. HPLC analysis of carotenoids in four varieties of Calendula Officinalis L. flowers. Acta Biologica Szegediensis. 2003;47(1-4):37-40.

14. Quezel P, Santa S. Nouvelle Flore de I'Algérie et régions désertiques méridionales. Tome 2. Centre national de la recherche, Paris. p. 565;1962.

15. Benhammou N, Atik-Bekkara F, Kadifkova PT. Antiradical capacity of the phenolic compounds of Pistacia lentiscus $L$ and Pistacia atlantica Desf. Adv Food Sci. 2007;29(3):155-61.

16. Oyaizu M. Studies on products of browning reactions: antioxidative activates of products of browning reaction prepared from glucosamine. Japan J Nutri. 1986;103:413-9.

17. Ozsoy N, Can A, Yanardag R, Akev A. Antioxidant activity of Smilax Excelsa L. leaf extracts. Food Chemistry. 2008;110(3):571-83.

18. De-la RLA, Alvarez PE, Gonzalez GA. Fruit and vegetable phytochemicals: Chemistry, Nutritional Value and Stability. John Wiley and sons.p.380;2009.

19. Adler G, Kasprzyk Z. Free sterols, steryl esters, glycosides, acylated glycosides and water-soluble complexes in Calendula Officinalis. Photochemistry. 1975;14(3):627-31.

20. Wilkomerski B. Pentacyclic triterpene triols from Calendula Officinalis flowers. Photochemistry. 1985; 24(12):3066-7.

21. Zitterl E, Sosa S, Jurenitsch J, Schubert Z, Della loggia R, Tubaro A, et al. Antioedematous activities of the main triterpendiol esters of marigold (Calendula officinalis L). journal of ethnopharmacology. 1997;57(2):139-44.

22. Badami RC, Morris LJ. The oxygenated fatty acid of Calendula seeds oil. The Journal of the American Oil Chemist's Society. 1965;42(12):1119-21.

23. Abdul-jalill R. GC-MS analysis of Calendula Officinalis and cytotoxic effects of its flower crude extract on human epidermoid larynx carcinoma (hep-2). World journal of pharmacy and pharmaceutical sciences. 2014;3(4):237-75.

24. Belabbes R. Enquête ethnobotanique, caractérisation chimique et activités biologiques des volatils de deux plantes médicinales de l'ouest Algérien: Calendula arvensis L et Carthamus sp L. M.Sc. Thesis, University Abou Bekr belkaïd, Tlemcen, Algeria. 2014.

25. Kassim GK, Fouad RS, Faroun AE. Antibiofilm, Antibacterial and Antioxidant activities of water extract of Calendula officinalis flowers. International journal of Biological and Pharmaceutical Research. 2013;4(7):465-70.

\section{GRAPHICAL ABSTRACT}

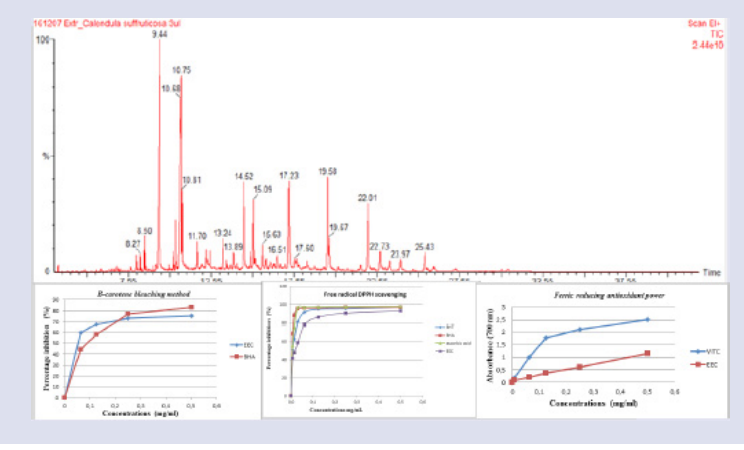

\section{SUMMARY}

- Calendula suffruticosa ssp. suffruticosa Vahl, Medicinal and Aromatic plant, spontaneous and widespread in the Mediterranean region and in the northeast of Algeria.

- Sixty-four compounds are identified by GC/MS analysis of the ethanolic extract , six are predominant : $\alpha$-linoleic acid $(24.20 \%)$, linoleic acid $(23.58 \%)$, Stigmasterol (8.53\%), 2-Metyl-Z-4-tetradecene (6.62\%) And $\alpha$-Bisabolol (1.70\%).

- The free radical scavenging by DPPH method indicated that the ethanolic extract of $\mathrm{C}$. suffruticosa showed a very high antioxydant activity with an $\mathrm{IC}_{50}=$ $0.017 \pm 1.00 \mathrm{mg} / \mathrm{ml}$.

- This extract also showed an ability to reduce very high iron with a maximum optical density of 1.157 at a concentration of $0.5 \mathrm{mg} / \mathrm{ml}$ and an antioxidant activity compared to the $\beta$-carotene / linoleic acid test of order of $75 \pm 1.02 \%$. 


\section{ABOUT AUTHORS}

Ismahene Sofiane: Ph.D in Laboratory of Plant Biology and Environment "Medicinal Plants" Axis, Departement of Biology, Faculty of Sciences, University Badji Mokhtar Annaba. Bp 12, 23000 Annaba. Algeria.

Ratiba Seridi: Presently, working as Director of Laboratory of Plant Biology and Environment "Medicinal Plants" Axis,and Professor in Departement of Biology, Faculty of Sciences, University Badji Mokhtar Annaba. Bp 12, 23000 Annaba. Algeria.

Diego Cortes: Presently, working as Director of Laboratory of Pharmacognosy, and Professor in Faculty of Pharmacy, University of Valencia, Av. Vicent Andrés Estelles s / n 46100 Burjassot, Valencia Spain.

Nuria Cabedo: Doctor, Laboratory of Pharmacognosy, Faculty of Pharmacy, University of Valencia, Av. Vicent Andrés Estelles s / n 46100 Burjassot, Valencia Spain.

Cite this article: Sofiane I, Seridi R, Cortes DM, Cabedo N. Phytochemical Composition and Evaluation of the Antioxidant Activity of the Ethanolic Extract of Calendula suffruticosa subsp. suffruticosa Vahl. Pharmacog J. 2018;10(1):64-70. 